Research article

\title{
MACRO-ELEMENTS COMPOSITION OF CYSTIC AND FOLLICULAR FLUID IN THE OVARIES AND THEIR RELATIONSHIP TO PERIPHERAL BLOOD CONCENTRATION IN SOWS
}

\author{
STANKIEWICZ Tomasz*, BŁASZCZYK Barbara
}

West Pomeranian University of Technology, Szczecin, Faculty of Biotechnology and Animal Husbandry, Department of Animal Reproduction Biotechnology and Environmental Hygiene, 6 Doktora Judyma Street, 71-466 Szczecin, Poland

(Received 22 ${ }^{\text {nd }}$ July 2014; Accepted $3^{\text {rd }}$ March 2015)

The aim of this work is the comparison of sodium, calcium, magnesium and phosphorus concentration in pre-ovulatory follicles and follicular cysts and their concentration in the serum of sows. The research was conducted on sows (Polish Large White $\mathrm{x}$ Polish Landrace crossbred). Sodium concentration in cystic fluid was higher than in the follicular fluid $(\mathrm{P}<0.05)$. Sodium concentration in the serum of cysts-bearing sows was higher than in non-cysts-bearing sows $(\mathrm{P}<0.01)$. Differences were also observed between cysts and serum of cysts-bearing sows $(\mathrm{P}<0.01)$, as well as follicles and serum of non-cysts-bearing sows $(\mathrm{P}<0.01)$. Calcium concentration in the serum of non-cystsbearing sows was higher than in the case of cysts-bearing sows $(\mathrm{P}<0.01)$. Differences were also between calcium concentration in the cysts and its concentration in the serum of cysts-bearing sows $(\mathrm{P}<0.05)$. Magnesium concentration in the serum of cysts-bearing sows was lower than in non-cysts-bearing sows $(\mathrm{P}<0.01)$. Differences in magnesium concentration were also between cysts and serum of cysts-bearing sows $(\mathrm{P}<0.01)$, as well as between follicles and serum of non-cysts-bearing sows $(\mathrm{P}<0.05)$. Phosphorus concentration in the cysts was lower than in the follicles $(\mathrm{P}<0.05)$. It was also lower in the serum of non-cysts-bearing sows than in the follicles $(\mathrm{P}<0.05)$. The concentration of sodium, magnesium and phosphorus in the serum was positively correlated with the concentration of the mentioned macro-elements in ovarian structures $(\mathrm{r}=0.66$, $\mathrm{P}<0.01 ; \mathrm{r}=0.49$, and $\mathrm{r}=0.48, \mathrm{P}<0.05$, respectively). A negative correlation was found between the concentration of serum calcium and the ovarian structures $(\mathrm{r}=-0.47$, $\mathrm{P}<0.05)$.

The differences in the concentrations of macro-elements suggest that the ionic composition may be one of the factors associated with the processes occurring in the ovarian structures of pigs.

Key words: ovarian follicular cysts, pre-ovulatory follicles, sodium, calcium, magnesium, phosphorus, sows

\footnotetext{
*Corresponding author: e-mail: tomasz.stankiewicz@zut.edu.pl
} 


\section{INTRODUCTION}

Follicular fluid is a complex combination of water and dissolved substances that originate from the plasma and are produced locally by cells of ovarian follicles. Its biochemical composition is of the utmost importance since when it is accumulated in the antrum, it influences follicle steroidogenesis, maturity and quality of oocytes, ovulation and transport of oocytes to the oviduct, as well as further creation of corpus luteum [1,2]. The knowledge of the biochemical composition of follicular fluid provides various information regarding the requirements for follicle cells and oocytes in in vitro conditions [2-5]. Moreover, the concentration of biochemical elements in the follicular fluid, both organic and mineral, reflects the changes in the secretory processes of the granulosa cells and theca interna cells, as well as compositional changes in plasma that are caused by physiological and pathological processes [1,6-8]. Balance disturbances between various elements of follicular fluid might cause disruption of follicle development causing some pathological conditions that include development of follicular cysts [9]. The pathogenesis of polycystic ovary syndrome is also connected with changes in permeability of the blood-follicle barrier [10].

Ovarian cysts constitute a high percentage of disorders of the functions of ovaries in sows [11,12]. Multiple ovarian cysts present in both ovaries are of especially high clinical importance because polycystic ovaries cause reproductive disorders and reduce reproductive performance in these sows, leading to culling from the herd $[12,13]$. Pathogenesis of these disorders has not been fully understood yet, however, such disorders might be reflected in biochemical changes regarding not only organic, but also mineral elements in both the local follicle environment and the peripheral blood. Therefore, the aim of this work is to compare the concentration of macro-elements (sodium, calcium, magnesium, phosphorus) in pre-ovulatory follicular fluid, follicular cysts and the concentration of these parameters in the serum of sows.

\section{MATERIALS AND METHODS}

The research was conducted on Polish Large White $\mathrm{x}$ Polish Landrace crossbred pigs at three years of age, slaughtered at the local slaughterhouse. During slaughter, samples of blood were taken from the external jugular vein of each sow and placed in the serum separator tube. Blood was centrifuged at $1000 \mathrm{x} g$ for 15 minutes and the obtained serum was then analysed. In total, 46 sows were examined, including 20 cysts-bearing sows and 26 sows which were determined not to have ovarian cysts and in which pre-ovulatory follicles were present in the ovaries.

For material homogeneity, only bilateral polycystic ovaries were allotted to the analysis. They were diagnosed based on the presence of several fluid-filled ovarian structures (above $20 \mathrm{~mm}$ ), with a thin and smooth wall and no corpus luteum [11,13,14]. Ovaries, during the pre-ovulatory phase, were determined based on the presence of over a dozen ovarian follicles with the diameter from 7 to $9 \mathrm{~mm}$, their colour, structure and lack of corpora lutea $[15,16]$. 
Follicular fluid was aspirated by means of a needle and a syringe from pre-ovulatory follicles (well vascularised and with a shiny surface) and fluid from follicular cysts with a diameter from 20 to $40 \mathrm{~mm}$. Each sow was assigned one fluid sample (cystic or preovulatory) and a corresponding serum sample.

Potentiometric concentration of sodium ions $\left(\mathrm{Na}^{+}\right)$and colorimetric concentration of total calcium $(\mathrm{Ca})$, magnesium $(\mathrm{Mg})$ and phosphorus $(\mathrm{P})$ were determined in the obtained samples with the Ortho Clinical Diagnostics Vitros 5.1 FS Chemistry System (Johnson \& Johnson's). Sodium concentrations outside the reportable (dynamic) range are not expected for this method. Reportable (dynamic) range for $\mathrm{Ca}, \mathrm{Mg}$ and $\mathrm{P}$ were $0.25-3.49 \mathrm{mmol} / \mathrm{L}, 0.08-4.11 \mathrm{mmol} / \mathrm{L}$ and $0.16-4.20 \mathrm{mmol} / \mathrm{L}$, respectively. For phosphorus concentration, if the concentration was above the upper end of the systems' reportable (dynamic) range, the samples were properly dissolved, in accordance with manufacturer's methodological recommendations.

\section{Statistic al analysis}

The obtained results were subject to statistical analysis. They were presented as an mean \pm standard deviation of the mean and presented on graphs. The differences in the ovarian structure groups and the serum of sows with cysts and without cysts were examined using the variance analysis and a posthoc test. Duncan's multiple range test was used to verify the significance of differences at $\mathrm{p}<0.05$ and $\mathrm{p}<0.01$.

In addition, correlations between the macro-elements in ovarian structures and serum were calculated with the Spearman rank correlation coefficient.

Statistical analyses were conducted using the STATISTICA version 7.1, Stat Soft, Poland.

\section{RESULTS}

As presented in Figure 1 the mean sodium concentration in the follicular cysts fluid amounted to $139.35 \pm 3.16 \mathrm{mmol} / \mathrm{L}$ and was significantly higher than in the preovulatory follicles fluid $(128.44 \pm 10.29 \mathrm{mmol} / \mathrm{L})$. Concentration of this element was also significantly higher in the serum of cysts-bearing sows $(156.93 \pm 6.30 \mathrm{mmol} / \mathrm{L})$ than in the serum of non-cysts-bearing sows $(147.44 \pm 10.58 \mathrm{mmol} / \mathrm{L})$. Significant differences in sodium concentration might also be observed between follicular cysts and serum of cysts-bearing sows $(\mathrm{P}<0.01)$, as well as between pre-ovulatory follicles and serum of non-cysts-bearing sows $(\mathrm{P}<0.01)$.

As presented in Figure 2 the mean calcium concentration was significantly higher in the serum of non-cysts-bearing sows $(2.01 \pm 0.58 \mathrm{mmol} / \mathrm{L})$ than in the serum of sows with cysts $(1.31 \pm 0.25 \mathrm{mmol} / \mathrm{L})$. On the other hand, the concentration of calcium in the follicular cysts fluid was higher $(2.35 \pm 0.11 \mathrm{mmol} / \mathrm{L})$ than in pre-ovulatory follicles $(2.17 \pm 0.39 \mathrm{mmol} / \mathrm{L})$, but the differences were not statistically significant. Significant differences were, however, identified between the concentration of calcium in follicular cysts and its concentration in the serum of cysts-bearing sows $(\mathrm{P}<0.05)$. 


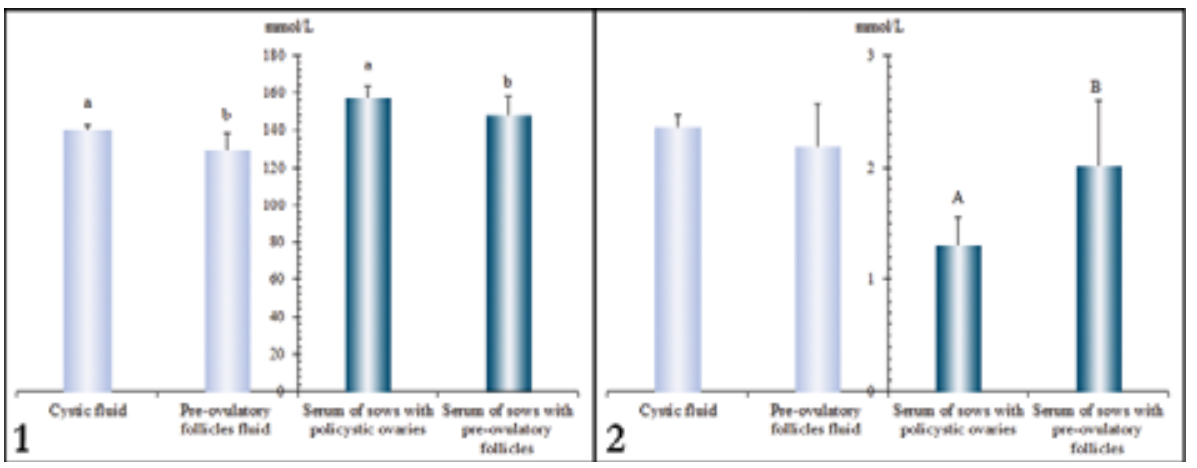

Figure 1. Sodium concentration in the follicular cystic fluid, pre-ovulatory follicular fluid, and serum in sows. Values are mean $\pm \mathrm{SD}$. a - mean values marked with various letter differ at $\mathrm{P}<0.05$ within the same color columns.

Figure 2. Calcium concentration in the follicular cystic fluid, pre-ovulatory follicular fluid, and serum in sows. Values are mean $\pm \mathrm{SD}$. A - mean values marked with various letter differ at $\mathrm{P}<0.01$ within the same color columns.

The mean magnesium concentration in follicular cysts amounted to $0.97 \pm 0.21 \mathrm{mmol} / \mathrm{L}$, and in pre-ovulatory follicles in amounted to $1.19 \pm 0.25 \mathrm{mmol} / \mathrm{L}$ (Fig. 3.). Further, it measured $0.52 \pm 0.15 \mathrm{mmol} / \mathrm{L}$ in the serum of sows with cysts and was significantly lower than in the serum of sows without cysts $(0.94 \pm 0.31 \mathrm{mmol} / \mathrm{L})$. Significant differences in magnesium concentration were also identified between follicular cysts and serum of cysts-bearing sows $(\mathrm{P}<0.01)$, as well as between pre-ovulatory follicles and serum of non-cysts-bearing sows $(\mathrm{P}<0.05)$.

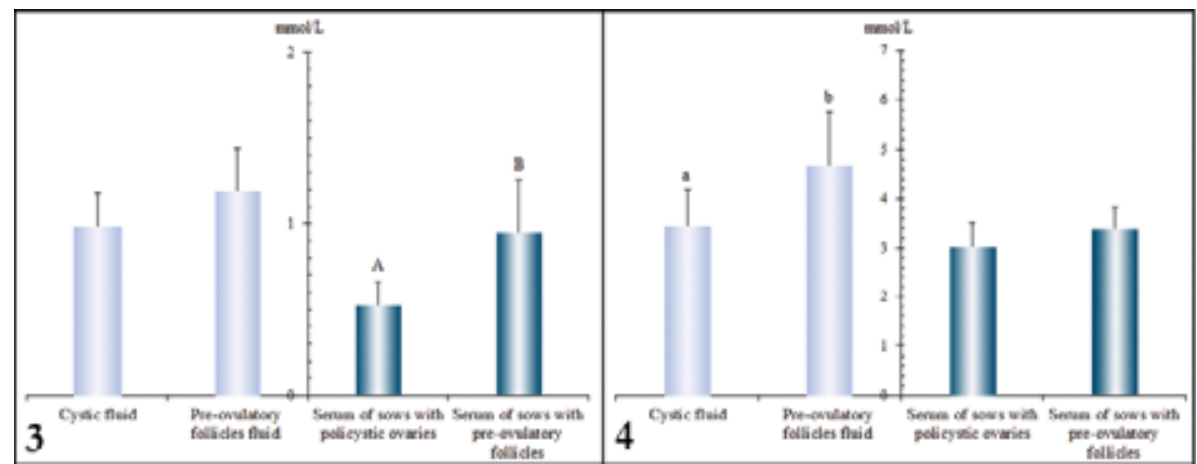

Figure 3. Magnesium concentration in the follicular cystic fluid, pre-ovulatory follicular fluid, and serum in sows. Values are mean $\pm \mathrm{SD}$. A - mean values marked with various letter differ at $\mathrm{P}<0.01$ within the same color columns.

Figure 4. Phosphorus concentration in the follicular cystic fluid, pre-ovulatory follicular fluid, and serum in sows. Values are mean \pm SD. a - mean values marked with various letter differ at $\mathrm{P}<0.05$ within the same color columns.

As presented in Figure 4 the mean phosphorus concentration in follicular cysts measured $3.42 \pm 0.76 \mathrm{mmol} / \mathrm{L}$ and was significantly lower than in pre-ovulatory follicles 
(4.67 $\pm 1.08 \mathrm{mmol} / \mathrm{L})$. It amounted to $3.01 \pm 0.51$ and $3.39 \pm 0.44 \mathrm{mmol} / \mathrm{L}$ in serums of cysts-bearing and non-cysts-bearing sows, respectively. Phosphorus concentration in serum of sows without cysts was lower than in pre-ovulatory follicles $(\mathrm{P}<0.05)$.

The concentration of sodium, magnesium and phosphorus in serum was positively correlated with the concentration of the macro-elements in ovarian structures $(\mathrm{r}=$ $0.66, \mathrm{P}<0.01 ; \mathrm{r}=0.49$, and $\mathrm{r}=0.48, \mathrm{P}<0.05$, respectively). A negative correlation was found between the concentration of serum calcium and ovarian structures $(r=-0.47$, $\mathrm{P}<0.05)$.

\section{DISCUSSION}

The presence of minerals in the ovarian follicles fluid and their part in the proper folliculogenesis and maturity of oocytes in various species of animals has been previously explained $[1,17,18]$. Therefore, this work does not only specify the concentration of basic macro-elements in pre-ovulatory follicles fluid or sows' follicular cysts, as well as their serum.

The concentration of sodium in the serum of both cysts-bearing and non-cystsbearing sows was similar to the examples of its concentration in pigs presented by other authors $[19,20]$ and is within the range of reference values provided by Winnicka [21]. Similarly to this work, the concentration of sodium in the serum (or blood's plasma) was higher in the ovarian follicles fluid in cows and buffalos, as noted in other works $[6,7,22]$. However, it was determined that sodium concentration higher in cystic fluid than in the pre-ovulatory follicles fluid might be caused by disorders of follicular fluid production. Since sodium is the main electrolyte of the extracellular fluid, it takes part in regulating the water and electrolyte balance thanks to osmotic pressure, as well as plays an essential part in regulating the permeability of the cell membrane. At the level of ovarian follicles, it influences changes in the permeability of theca capillaries and plays part in the mechanism of follicular fluid accumulation $[23,24]$.

Total calcium was another examined macro-element. Its concentration in the serum was lower than in pre-ovulatory follicles, similarly as in the case of cows [25]. Calcium concentration in the serum of sows without cysts was similar to its concentration in the serum of pigs [19-21]. However, the concentration of calcium in the serum of sows with cysts was much lower than in the case of sows without cysts. It might suggest that a deficit of this macro-element in the peripheral circulation may constitute a factor which facilitates the creation of follicular cysts. When treating the polycystic ovary syndrome in human medicine, it is emphasised that supplementation of calcium and vitamin D is effective [26]. Moreover, calcium plays a significant part in animal reproduction and its deficiency exerts an adverse influence on their fertility [27]. In ovarian follicles it also participates in processes connected with meiotic maturation of oocytes, in gonadotropin regulation of steroidogenesis and ovulation, as well as in atresia of follicles $[1,28]$. On the other hand, it has been proven that there is a positive correlation between calcium concentration in the ovarian fluid and the number of 
degenerated oocytes in dairy cows [22]. It cannot be ruled out that the concentration of calcium higher in the cystic fluid than in pre-ovulatory follicles fluid presented in this work might be connected with the distorted local regulation of this macroelement during the follicle development.

Magnesium concentration in the serum of sows without cysts was comparable to the one observed in pigs $[20,29]$. However, it was significantly lower in the serum of cysts-bearing sows than in non-cysts-bearing sows and set below the values observed in serum of pigs. These findings show that, similarly to calcium, low concentration of magnesium in peripheral circulation might be a factor contributing to the creation of ovarian cysts. On the level of ovarian follicles, magnesium influences the production of thrombin and the activity of mitogenic follicular cells [25]. In this work, its concentration in follicles and cysts was similar and comparable to those already reported in the fluid of large ovarian follicles of sheep [1]. The concentration of magnesium, however, was lower in the serum of sows than in cysts or pre-ovulatory follicles. Concentrations of this macro-element lower in the serum than in ovarian follicles was also observed in cows [25]. These relations developed differently in buffalos as in their case magnesium and calcium concentrations were higher in blood plasma than in the follicular fluid [7].

Phosphorus concentration in the serum of both cysts-bearing and non-cysts-bearing sows was similar and comparable to the concentration observed in pigs presented in other works $[20,30,31]$. These values were close to the upper limit of reference values provided by Winnicka [21]. The concentration of phosphorus lower in the cystic fluid than in pre-ovulatory follicles, presented in this work, might be connected with different intensities of metabolic processes in pathological and physiological ovary structures, as phosphorus takes part in various reactions, mainly through participation in the synthesis of phospholipids, cyclic adenosine 3' and 5'-monophosphate (cAMP). Its relation to seasonal changes in ovarian activity in buffalos was also presented [32]. However, Abd Ellah et al. [33] showed the relation between that macro-element and the phase of the estrous cycle. The study cited above showed that follicular phosphorus concentration was higher at estrus and metestrus than at the proestrus and diestrus stages in buffalo cows.

\section{CONCLUSIONS}

The differences in the concentrations of macro-elements suggest that the ionic composition may be one of the factors associated with processes occurring in the ovarian structures of pigs.

\section{REFERENCES}

1. Nandi S, Kumar VG, Manjunatha BM, Gupta PS: Biochemical composition of ovine follicular fluid in relation to follicle size. Develop Growth Differ 2007, 49: 61-66.

2. Stankiewicz T, Błaszczyk B, Udała J: Selected aspects of pig oocytes maturation in vivo and in vitro. Med Weter 2008, 64: 400-403 (in Polish). 
3. Błaszczyk B, Stankiewicz T, Udała J, Gączarzewicz D, Lasota B, Błaszczyk P, Szymańska A, Szymańska-Pasternak J: Free thyroid hormones and cholesterol in follicular fluid of bovine ovaries. Bull Vet Inst Pulawy 2006, 50: 189-193.

4. Stankiewicz T, Błaszczyk B, Lasota B, Gączarzewicz D, Udała J: Saisonabhängige Veränderungen der Ovargröße sowie Konzentration von Steroidhormonen und Thyroxin in der Follikelflüssigkeit beim Schwein. Tierarztl Prax 2008, 36: 99-103.

5. Stankiewicz T, Błaszczyk B, Udała J: A Study on the Occurrence of Polyovular Follicles in Porcine Ovaries with Particular Reference to Intrafollicular Hormone Concentrations, Quality of Oocytes and their in vitro Fertilization. Anat Histol Embryol 2009, 38: 233-239.

6. Leroy JL, Vanholder T, Delanghe JR, Opsomer G, Van Soom A, Bols PE, de Kruif A: Metabolite and ionic composition of follicular fluid from different-sized follicles and their relationship to serum in dairy cows. Anim Reprod Sci 2004, 80: 201-211.

7. Arshad HM, Ahmad N, Rahman ZU, Samad HA, Akhtar N, Ali S: Studies on some biochemical constituents of ovarian follicular fluid and peripheral blood in buffaloes. Pak Vet J 2005, 25: 189-193.

8. Stankiewicz T, Błaszczyk B: Concentrations of bone morphogenetic protein-15 (bmp$15)$ and growth differentiation factor- 9 (gdf-9) in follicular cysts, mono - and polyoocyte follicles in gilts, Acta Vet-Beograd 2014, 64: 24-32.

9. Khan FA, Das GK, Pande M, Pathak MK, Sarkar M: Biochemical and hormonal composition of follicular cysts in water buffalo (Bubalus bubalis). Anim Reprod Sci 2011, 124: 61-64.

10. Zhou H, Ohno N, Terada N, Saitoh S, Naito I, Ohno S: Permselectivity of blood follicle barriers in mouse ovaries of the mifepristone-induced polycystic ovary model revealed by in vivo cryotechnique. Reproduction 2008, 136: 599-610.

11. Cech S, Dolezel R: Treatment of ovarian cysts in sows - a field trial. Vet Med-Czech 2007, 52, 413-418.

12. Szulańczyk-Mencel K, Rząsa A, Bielas W: Relationships between ovarian cysts and morphological and hormonal state of ovarian cortex in sows. Anim Reprod Sci 2010, 121: 273-278.

13. Heinonen M, Leppävuori A, Pyörälä S: Evaluation of reproductive failure of female pigs based on slaughterhouse material and herd record survey. Anim Reprod Sci 1998, 52: 235244.

14. Sun YL, Ping ZG, Li CJ, Sun YF, Yi KL, Chen L, Li XY, Wang XL, Zhou X: Comparative Proteomic Analysis of Follicular Fluids from Normal and Cystic Follicles in Sows. Reprod Dom Anim 2011, 46, 889-895.

15. Hunter MG, Robinson RS, Mann GE, Webb R: Endocrine and paracrine control of follicular development and ovulation rate in farm species. Anim Reprod Sci 2004, 82-83: 461-477.

16. Paradis F, Novak S, Murdoch GK, Dyck MK, Dixon WT, Foxcroft GR: Temporal regulation of BMP2, BMP6, BMP15, GDF9, BMPR1A, MPR1B, BMPR2 and TGFBR1 mRNA expression in the oocyte, granulosa and theca cells of developing preovulatory follicles in the pig. Reproduction 2009, 138: 115-129.

17. Kaur J, Takkar OP, Khera KS, Chaudhary KC, Rajvir S, Kaur J, Singh R:. Mineral elements in follicular fluid of buffalo ovary. Indian J Anim Reprod 1997, 18: 36-38.

18. Bordoloi PK, Sarmah BC, Dutta DJ, Deka BC: Macro and micro minerals in caprine follicular fluid. Indian J Anim Reprod 2001, 22: 23-25. 
19. Prvulović D, Jovanović-Galović A, Stanić B, Popović M, Grubor-Lajšić G: Effects of a clinoptilolite supplement in pig diets on performance and serum parameters. Czech J Anim Sci 2007, 52: 159-164.

20. Dobrzański Z, Pogoda-Sewerniak K, Dragan S, Korniewicz D, Hoffmann K, Korniewicz A: Effect of Various Feed Phosphates on Biochemical Indices of Blood and Mineral Composition of Bones in Finishing Pigs. Acta Vet Brno 2010, 79: 355-361.

21. Winnicka A: Reference values of basic laboratory analysis in veterinary medicine. Ed SGGW Warszawa 2008, (in Polish).

22. Alves BG, Alves KA, Lúcio AC, Martins MC, Silva TH, Alves BG, Braga LS, Silva TV, Viu MA, Beletti ME, Jacomini JO, Santos RM, Gambarini ML: Ovarian activity and oocyte quality associated with the biochemical profile of serum and follicular fluid from Girolando dairy cows postpartum. Anim Reprod Sci 2014, 146: 117-125.

23. Sharma RK, Vats R, Sawhney A: Changes in electrolytes of antral follicles in goat. Indian J Anim Reprod 1995, 16: 18-21.

24. Rodgers RJ, Irving-Rodgers HF: Formation of the Ovarian Follicular Antrum and Follicular Fluid. Biol Reprod 2010, 82: 1021-1029.

25. Yamada M, Hirakushi K, Inoue K, Horiuchi T, Sakai J, Okada T, Sugie I: Magnesium as a regulator of thrombin formation in bovine ovarian follicular fluid. J Vet Med Sci 1998, 60: $837-842$.

26. Firouzabadi Rd, Aflatoonian A, Modarresi S, Sekhavat L, MohammadTaheri S: Therapeutic effects of calcium \& vitamin D supplementation in women with PCOS. Complement Ther Clin Pract 2012, 18: 85-88.

27. Subha G: Role of Biochemical factors and Mineral Supplementation in Livestock ration for Maintenance of their Fertility and Healthy Reproductive Status: A Review. Res J Chem Sci 2013, 3: 102-106.

28. Lebedeva IY, Denisenko VY, Lebedev VA, Kuzmina TI: Prolactinin follicular fluid and intracellular store calcium in follicular cells are related to morphological signs of ovarian follicle atresia in cows: work in progress. Theriogenology 1998, 49: 509-519.

29. Klem TB, Bleken E, Morberg H, Thoresen SI, Framstad T: Hematologic and biochemical reference intervals for Norwegian crossbreed grower pigs. Vet Clin Pathol 2010, 39: 221 226.

30. Dubreuil P, Lapierre H: Biochemistry Reference Values for Quebec Lactating Dairy Cows, Nursing Sows, Growing Pigs and Calves. Can J Vet Res 1997, 61: 235-239.

31. Cooper CA, Moraes LE, Murray JD, Owens SD: Hematologic and biochemical reference intervals for specific pathogen free 6-week-old Hampshire-Yorkshire crossbred pigs. J Anim Sci Biotechnol 2014, 5: 1-5.

32. Jayachandran S, Nanjappan K, Muralidharan J, Selvaraj P, Manoharan A: Blood biochemical and mineral status in cyclic and postpartum anestrus buffaloes. Int J Food Agri Vet Sci 2013, 3: 93-97.

33. Abd Ellah MR, Hussein HA, Derar DR: Ovarian Follicular Fluid Constituents in Relation to Stage of Estrus Cycle and Size of the Follicle in Buffalo. Vet World 2010, 3: 263-267. 


\title{
ODNOS SASTAVA MAKROELEMENATA FOLIKULARNE I CISTIČNE TEČNOSTI JAJNIKA I NJIHOVE KONCENTRACIJE U PERIFERNOJ KRVI KRMAČA
}

\author{
STANKIEWICZ Tomasz, BEASZCZYK Barbara
}

Cilj ovog rada je poređenje koncentracije natrijuma, kalcijuma, magnezijuma i fosfora u pre - ovulatornim folikulima i folikularnim cistama i njihove koncentracije u krvnom serumu krmača. Istraživanje je sprovedeno na krmačama (poljska velika bela x poljski landras). Koncentracija natrijuma u cističnoj tečnosti bila je veća nego u folikularnoj tečnosti $(\mathrm{p}<0.05)$. Koncentracija natrijuma u serumu krmača sa ovarijalnim cistama bila je veća nego kod krmača koje nisu imale ciste $(p<0,01)$. Razlike su takođe primećene između koncentracija $\mathrm{Na} u$ sadržaju cisti i krvnom serumu krmača bez cisti $(\mathrm{p}<0,01)$, kao i između koncentracija u sadržaju folikula i seruma krmača bez cisti. Koncentracije kalcijuma u serumu krmača bez cisti bio je veći nego kod krmača sa cistama $(\mathrm{p}<0,01)$. Takođe su uočene razlike između koncentracije kalcijuma u cistama i njegove koncentracije u serumu krmača sa ovarijalnim cistama $(p<0,05)$. Koncentracija magnezijuma u serumu krmača sa ovarijalnim cistama bila je niža nego kod nego kod krmača kod kojih nije zabeleženo prisustvo cista na jajnicima $(p<0,01)$. Takođe su zabeležene razlike u koncentraciji magnezijuma u sadržaju cista i u serumu krmača sa cistama ( $\mathrm{p}<0,01)$, kao i između koncentracije Mg u sadržaju folikula i seruma krmača bez cisti $(p<0,05)$. Koncentracija fosfora u cistama bila je niža nego u folikulima $(p<0,05)$. Takodje, koncentracija fosfora je bila niza u serumu krmača bez cisti $(p<0,05)$. Koncentracija natrijuma, magnezijuma i fosfora u serumu bila je u pozitivnoj korelaciji sa koncentracijom navedenih makro- elemenata u strukturama jajnika ( $\mathrm{r}=$ $0,66, \mathrm{p}<0,01 ; \mathrm{r}=0,49 ; \mathrm{r}=0,48, \mathrm{p}<0,05)$. Ustanovljena je negativna korelacija izmedu koncentracije kalcijuma u serumu i u strukturi jajnika $(\mathrm{R}=-0,47, \mathrm{p}<0,05)$.

Razlike u koncentracijama makro elemenata sugerišu da jonski sastav može biti jedan od faktora koji su povezani sa procesima koji nastaju u strukturama jajnika svinja. 